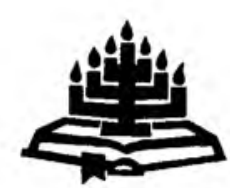

\title{
Volharding as sentrale gegewe in die boek Openbaring
}

\author{
A.G.S. Venter en Jan A. du Rand \\ Departement Bybelkunde \\ Randse Afrikaanse Universiteit \\ JOHANNESBURG \\ E-pos: jadr@lw rau.ac.za
}

\begin{abstract}
Perseverance as central issue in the Book of Revelation

This article attempts to indicate that the Book of Revelation as an apocalypse has a special way of inducing its readers, the church, to listen to its message. The Book of Revelation depicts the church as experiencing specific internal and external problems. $A$ solution to these problems is founded in a theocentric perspective - a perspective in which the deeds of God are the foundation by which the church perseveres. The Book of Revelation describes the persevering activities of the church in its proclamation of the gospel, its liturgical activities, its reading of Scripture, hymns and prayers and its actions aimed at purifying the church of unacceptable influences.
\end{abstract}

\section{Inleiding}

Die mensbeskouing (die antropologie) van Openbaring is 'n verwaarloosde onderwerp in ondersoeke oor die boek Openbaring (vgl. Fuller, 1983:304). Dit is byvoorbeeld 'n leemte dat oorkoepelende studies oor die begrip volharding in Openbaring nog nie gedoen is nie. Intussen is verklaarders dit eens dat die volharding van die gelowiges 'n wesenlike aspek van die boodskap van Openbaring is. Hierdie artikel poog om 'n bydrae te maak om hierdie leemte te vul.

Navorsing oor Openbaring behandel meestal die meer formele aspekte daarvan, byvoorbeeld die verklaringsbeginsels, die struktuur, inhoud en taalhandelinge, die agtergrond en apokaliptiese kenmerke van die boek. Die "teologie" van Openbaring kom heelwat aan die orde, maar wanneer dit oor die "ekklesiologie" handel, word hoofsaaklik op Openbaring 2 en 3 gekonsentreer. Hierdie artikel 
poog om uit die hele Openbaring die betekenis van die begrip volharding vir die kerk van vandag te omlyn.

Hierdie artikel is 'n eksegetiese ondersoek van bepaalde gegewens in Openbaring. Aan die hand van die standpunte van bekende kommentatore en teoloẻ en eie eksegetiese arbeid word telkens 'n moontlike verklaring gebied wat so naby as moontlik en so getrou as moontlik bevind word aan die bedoeling van die outeur van die boek Openbaring. Ander interpretasies is uiteraard moontlik. Die bevindinge, styl en inhoud van hierdie artikel moet in die lig van genoemde uitgangspunte besien word.

Eerstens word nagegaan op watter wyse Openbaring as profesie en apokalips hom spesifiek daartoe leen om 'n kragtige onderbou te bied vir die oproep tot volharding. Tweedens word nagegaan hoe Openbaring hom spesifiek tot die kerk rig - daarom moet die besonderhede in Openbaring oor die spesifieke situasie van die kerk nagevors word. Die probleme wat van buite af die kerk bedreig, word eers ondersoek en daarna Openbaring se gegewens oor die interne toestand van die kerk. Vervolgens word die basis vir die oproep en bemoediging tot volharding geformuleer vanuit die teosentriese perspektief dat Openbaring God in die middelpunt van alles stel. Laastens word nagegaan hoe Openbaring die praktiese, volhardende dade van die kerk beskryf.

Hierdie ondersoek behoort aktueel te wees vir gelowiges wat in 'n veeleisende wêreld moet leef. Die probleem wat om 'n oplossing vra, is: watter bemoediging bied Openbaring aan die kerk, die gelowiges, om onder moeilike omstandighede te volhard?

\section{Openbaring as profesie en apokailps spreek tot die kerk}

Die oproep en bemoediging uit Openbaring kan vir die kerk vandag van groot waarde wees, juis omdat Openbaring sigself aandien as 'n profesie $(1: 3 ; 22: 7,10$, 18, 19). Die betekenis van Openbaring kan beskryf word as 'n “... revelation [which] is an experience of Jesus Christ who now is present and speaks to the Christian community through the prophet" (Schüssler Fiorenza, 1980:127). As sodanig kon dit vir die eerste lesers ooreenkomste met die profete van die $\mathrm{Ou}$ Testament gehad het (Du Preez, 1979:11; Hill, 1971:402 e.v.) en leen hierdie feit hom daartoe om as basis van die aspek van bemoediging te dien.

Hand aan hand met die begrip profesie gaan die begrip openbaring in die "opskrif" van Openbaring, naamlik: "Die openbaring van Jesus Christus" (1:1). Die woord apokalips gee inderdaad 'n beskrywing van 'n belangrike eienskap van hierdie boek ('n openbaring), maar hierdie enkele woord kan nie alle tipiese 
kenmerke van Openbaring omvat nie. Die volgende aspekte is aanvullend vir hierdie ondersoek van belang:

- Die feit dat die openbaring "van Jesus Christus" af is (waarskynlik is die genitief 'n subjektiewe genitief - Charles, 1920a:6), gee daaraan gesag. As woorde van Jesus dra dit gesag en kan dit waarlik troos bied wanneer die gelowiges tot volharding opgeroep word.

- Die eskatologiese gerigtheid van die boek (Hill, 1971:403; Schüssler Fiorenza, 1980:110; Du Rand, 1990:180) is betekenisvol. Die wederkoms van Jesus Christus en alles wat daamee saamhang, is die hoogtepunt en eindpunt van God se redding wat $\mathrm{Hy}$ in die koms en werk van Jesus Christus begin het. Daarom het die eskatologiese beloftes betekenis gehad, en het dit steeds betekenis vir die hede en die onmiddellike toekoms van die lesers (Hill, 1971:403). Hierdie eskatologiese gerigtheid bied 'n kragtige basis vir die gegewens aangaande die volharding van die gelowiges.

- Die feit dat Openbaring as apokalips 'n transendente werklikheid skep, is betekenisvol. "Die lesers is as ' $t$ ware uit die moeilike omstandighede uitgelig om vanuit 'n ander, hemelse, werklikheid na die aardse omstandighede te kyk. Hierdie afstand wat geskep is, was die basis vir 'n meer objektiewe kyk na die huidige situasie" (Venter, 1995:26). Vanuit hierdie "objektiewe" perspektief kon die lesers destyds, en kan die lesers vandag, antwoorde formuleer wat onmoontlik is vir iemand wat nie hierdie besondere blik het nie.

- Om Openbaring reg te verstaan, moet die leser besef dat hierdie besondere boek 'n apokalips is wat die leser in 'n nuwe denkwêreld inlei, in 'n simboliese universum (Schüssler Fiorenza, 1986:125; Du Rand, 1990:164165). Die leser moet inbeweeg in die denkwêreld van simbole. En dit is die unieke van Openbaring, anders as die res van die Nuwe Testament waar feite en gebeure konkreet en op die naam genoem en beskryf word. Die gelowige wat hierdie simboliese universum sien, en die kragte in hierdie simboliese geheelbeeld nie net sien nie maar ook beleef, ontvang besondere krag om te volhard.

Dit is duidelik dat hierdie boek bedoel is vir gelowiges wat reeds insig in die Bybel en die evangelie van Jesus Christus het. Iemand moet die gesag van 'n profesie ken en moet die werklikheid van die evangelie glo om die simboliese werklikheid te kan sien en te kan beleef. Vir die gelowige wat hom of haar in hierdie simboliese werklikheid verdiep, lê in Openbaring as profesie en as apokalips 'n sterk basis om die oproep tot volharding ter harte te neem (1:3). 


\section{Openbaring spreek tot die kerk in sy konkrete situasie}

\subsection{Die aanslag teen die kerk}

Die boek Openbaring is gerig "aan die sewe gemeentes in die provinsie Asie" (Op. 1:4). Verklaarders is eenstemmig dat hierdie sewe gemeentes die hele kerk (al die kerke) verteenwoordig (Botha, 1965:73,125; Aune, 1966:133; Schüssler Fiorenza, 1968:562; Collins, 1983:6; Hughes, 1990:18; Venter, 1995:170).

Dat die kerk dringend van die inhoud van Openbaring moet kennis neem, blyk uit 1:3: "Geseënd is die een wat die woorde van hierdie profesie lees en die mense wat dit hoor en wat ter harte neem wat daarin geskrywe staan ..." (1983-vert.). In Openbaring ontstaan 'n retoriese verhouding tussen die Outeur, Jesus Christus, en die lesers. Uit hierdie retoriek kan afgelei word wat die vrae en probleme van die eerste lesers was en watter (retoriese) historiese situasie tot daardie vrae gelei het (Venter, 1995:50).

Reeds van die eerste hoofstuk af laat Openbaring blyk dat die kerk onder moeilike omstandighede leef. Die skrywer, Johannes, maak in 1:9 duidelik: "Ek, Johannes, is julle medegelowige, en deur ons verbondenheid met Jesus het ek saam met julle deel aan die verdrukking en aan die koninkryk en aan die

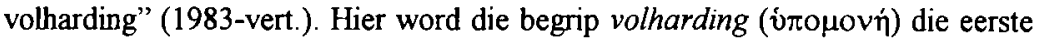
keer in Openbaring by name genoem (vgl. verder $1: 2,3,19 ; 3: 10 ; 13: 10 ; 14: 12$ ). In 1:9 word volharding spesifiek verbind aan Johannes se verkondiging van die Woord van God en die getuienis van Jesus Christus. Die feit dat Johannes gedoen het wat tipies van die kerk is, naamlik om die Woord te verkondig, het gelei tot sy verbanning na Patmos. Die kerk kan dus verwag om teenstand ( $\theta \lambda i ́$ is "verdrukking" in 1:9) te kry as die Woord van die koninkryk ( $\beta \alpha \sigma i \lambda \varepsilon i \alpha$ in 1:9) in waarheid verkondig word. Dan sal die kerk moet volhard (ijouoví in 1:9) (Venter, 1995:59, 60).

Hierdie teenstand en aanslae teen die kerk word verder duidelik uit Openbaring 2 en 3 in die sewe briefboodskappe aan die gemeentes in Klein-Asië. Dit blyk ook uit Openbaring 12 en 13 in die aanslag van die draak, met sy medewerkers, die diere uit die see en die aarde, teen die vrou, die kerk. Ook Openbaring 14-18 bied hiervan gegewens uit die voorstelling van die aanslag afkomstig van "die groot stad Babilon".

Die perspektief wat Openbaring 12-18 gee, is dat die kerk in wese gewikkel is in die konflik tussen God en die Satan. Die besonderhede van hierdie aanslag word nie in hierdie artikel behandel nie (vgl. Venter, 1995:64-80). Samevattend kan gestel word dat Openbaring die probleme van die kerk teken as komende van die Satan, die draak (12:1-17). Die dier uit die see (13:1-10) kan beskryf word as die mag en gesag van die anti-Christelike magte. Die dier uit die aarde (13:11-18) 
kan gesien word as die verraderlike aanslag om die mense tot afgodery en heidense praktyke te verlei. Die groot stad Babilon (vgl. 14:8; 16:19;17:5; 18:2, $10,21)$ is 'n simboliese voorstelling van die sametrekking van die menslike magte en ryke wat die menslike vermoëns teen God monster. Babilon is dus nie nét die stad Rome nie (soos beweer deur onder andere Charles, 1920b:14; Collins, 1988:66,68; Harrington, 1993:150), maar sluit ook Rome (die Romeinse regering) in, in soverre dit ' $n$ bedreiging vir die gelowiges was.

Volgens Openbaring 12-18 kon die gelowiges altyd seker wees dat God die oorwinning oor die Satan en sy magte beloof en gee. Hierdie feit is die basis vir hulle volharding soos pertinent blyk uit 13:10 en 14:12 (waar die begnip úrouoví by name genoem word). Die gelowige kan uiteindelik volhard omdat hy uit Openbaring verneem dat God oor die Satan triomfeer (12:9-11) en die Satan oorwin (o.a. 14:8-11). Hierdie teosentriese perspektief is 'n wesenlike aspek van die boodskap van Openbaring en 'n kragtige fundering vir die volharding van die kerk van Jesus Christus. Herhaaldelik weerklink die boodskap, as 'n refrein wat as 'n herhalende tema in Openbaring beskryf kan word (Venter, 1995:45), dat hoe heftig die aanslag van die Satan ook al is, dit futiel is omdat hy deur God vernietig (sal) word.

Dat hierdie stryd en die oorwinning nie iets is wat buite die gelowige se lewe afspeel nie, maar die kerk se bestaan daadwerklik raak, blyk duidelik uit die volgende gegewens in Openbaring. Daar kan onderskei word tussen probleme van buite die kerk en probleme van binne die kerk.

\subsection{Probleme van buite die kerk}

Openbaring noem kosmiese rampe en krisisse, onder andere gesimboliseer in die vier perde van Openbaring 6:1-8. Hierdie vier perde teken 'n beeld van lyding en ontbering en selfs die dood wat die mensdom tref (Venter, 1995:83). In 7:16, 17; 21:4, 6 word implisiet genoem dat die gelowiges honger, dors, son en hitte ondergaan.

Verder is daar in Openbaring sprake van probleme uit die samelewing.

\section{- Die Jode}

Eerstens was die Jode 'n groot bedreigende faktor $(2: 9 ; 3: 9)$, veral as hulle as "'n sinagoge van die Satan" beskryf word. Dit moes die Christene voor 'n teologiese probleem gestel het, omdat die Jode nie meer as die volk van God bestempel is nie, maar as 'n sinagoge van die Satan! Juis omdat die Christendom uit die Jodendom ontstaan het en ook op die vervulling van die Ou-Testamentiese profesieê gebou was, moes dit 'n werklike krisis vir die Christene gewees het veral dié wat gebore Jode was. Die feit dat die Christene hierdie fel en intense aanslag van die Jode die hoof gebied het, was vir hulle volharding as gelowiges 
baie werd. Versterk deur hierdie feit, kon hulle ook die ander krisisse hanteer (Hopkins, 1965:43).

\section{- Die owerheid en die bevolking}

Tweedens was die owerheid 'n bedreiging vir die Christene. Daar moet gewaak word om Babilon bloot met Rome te vereenselwig. Sekere aspekte waarvoor Babilon staan, kon wel op die owerheid van destyds van toepassing gemaak word (Venter, 1995:86, 87). Daar kan nie op grond van die beskikbare gegewens tot die slotsom gekom word dat 'n algemene vervolging die gelowiges bedreig het nie (Reddish, 1982:102). Daar is wel gegewens dat die keiser vergoddelik was (Schüssler Fiorenza, 1986:136). Alles in ag genome, is die hoofsaak van Openbaring nie om 'n reaktiewe geskrif te wees op die vergoddeliking van die keiser of vervolginge nie (soos Reddish, 1982:123). Eerder is dié boek 'n aansporing om te volhard (vgl. Mathews, 1993:306), wat ook al die teenstand of die verleiding sou wees.

Hiermee saam moet die invloed van die bevolking besien word. Dit is waarskynlik dat die Christene se eksklusiwiteit en monoteïsme daartoe kon gelei het dat hulle sporadiese en geïsoleerde teenstand gekry het van "die bewoners van die aarde" $(11: 10 ; 13: 8,12,14 ; 17: 2,8)$. Juis die feit dat die gelowiges volhard het in hulle Christenskap, kon tot teenstand gelei het. "Dan is Openbaring nie 'n nuwe oproep tot volharding nie, maar 'n versterkende aanmoediging om te bly volhard" (Venter, 1995:89) in 'n wêreld waar die gelowiges tussen die mense geleef het.

\section{- Lyding en martelaarskap}

Laastens 'n enkele woord oor die feit van lyding, martelaarskap en selfs die dood van gelowiges. Dat daar ' $n$ verband is tussen die getuienis ( $\mu \alpha \rho \tau$ rupí $\alpha$ ) wat die gelowiges oor Jesus Christus en oor die Woord van God gegee het en hulle lyding en in sommige gevalle selfs die dood, blyk uit $1: 9 ; 6: 9 ; 11: 7,8 ; 12: 11,17 ; 20: 4$. Die dood van die gelowiges word genoem in $6: 10,11 ; 16: 6 ; 17: 6 ; 18: 24 ; 19: 2$. In hierdie verband is 13:10 van belang, omdat hier sprake is van die volgende omstandighede: "As iemand (bestem) is vir gevangenskap, gaan hy in gevangenskap; as jemand (bestem) is om met 'n swaard doodgemaak word, word hy met 'n swaard doodgemaak. Hier is (nodig) volharding ( $(j o \mu \circ v i$ ) en geloof

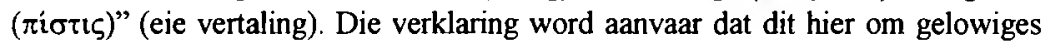
gaan wat die oproep direk hoor dat hulle in sulke omstandighede moet volhard en glo (vgl. Venter, 1995:93).

Uit hierdie gegewens blyk dit dat die aanslag van buite die kerk af baie fel was. Hulle eie mense (volksgenote), hulle eie bure (saam met wie hulle geleef en gewerk het) en hulle eie owerheid was 'n bedreiging vir die gelowiges. Om in sulke omstandighede in die geloof te volhard, sou groot eise aan die gelowiges 
gestel het. Die kerk het deur al die eeue hierdie aanslag ondervind. Vandag is dit ewe heftig en moet die moderne gelowige waaksaam wees om hierdie aanslag raak te sien.

\subsection{Probleme van binne die kerk}

Openbaring bied duidelike gegewens oor probleme wat van binne af die kerk bedreig het en die gelowiges onder druk sou geplaas het om te volhard.

\subsubsection{Verleiding}

\section{- Deelname aan heidense praktyke}

Die verleiding deur Isebel, waarskynlik 'n simboliese verwysing na die vrou van Agab in die Ou Testament, word in 2:20 genoem. Dat hierdie verleiding van binne die kerk afkomstig is, blyk daaruit dat sy as 'n "profetes" benoem word. Sy was klaarblyklik iemand van die gemeente wat 'n mate van aansien gehad het en na wie mense sou geluister het. Sy het daarin geslaag om van "die goeie lidmate" ("my diensknegte" - 2:20) te verlei (Venter, 1995:95). Dit is moontlik dat die "onsedelikheid" waarmee sy die gemeente verlei het, nie net metafories verstaan moet word nie (soos in 17:2;18:3,19), maar dat dit hier ook praktiese onsedelike dade kan insluit (Morris, 1969:72).

Dit is veelseggend dat 2:20-23 omraam word deur die gedagte van volharding. Die woord íouoví kom voor in $2: 19$ en in $2: 25,26$ is die sinonieme uit-

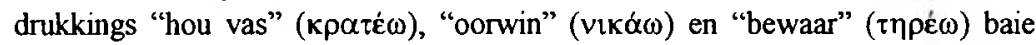
prominent. Die verleiding het groot eise aan die volharding van die gelowiges gestel. Dit was nie net in die gemeente in Tiatira die situasie nie, want "al die gemeentes" (2:23) moes hiema luister.

Hiermee saam is die sogenaamde "leer van Bileam" (2:14) van belang. Die raad van Bileam was om die volk van God te verlei deur met heidene te vermeng sodat hulle uiteindelik tot afgodediens verlei sou word (Numeri 22-24). Die gevaar om met heidense praktyke saam te gaan, was wesenlik. Hierteen sou die gelowiges daadwerklik en volhardend weerstand moes bied.

\section{- Blootstelling aan bederwende invloede}

Dat daar in die kerk "bederwende invloede" kan wees, blyk uit 2:2 waar sprake

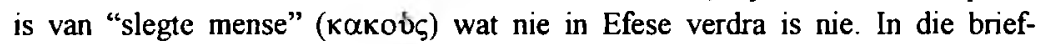
boodskap aan Sardis word genoem dat die gelowiges "besoedel" (3:4) kon word. Sulke "besoedelde" lidmate in "n gemeente hou die moontlikheid in van skadelike beïnvloeding van ander lidmate. Die implikasie is dat met volharding teen sodanige beïnvloeding gewaak moet word. 


\subsubsection{Dwaalleer}

Dwaalleer is in die gemeentes ingebring deur diegene "wat sê dat hulle apostels is en dit nie is nie" (2:2) en die sogenaamde Nikolaiete $(2: 6,15)$.

Die leer van die Nikolaïete word onderskei van "die leer van Bileam" (2:14) en van die verleiding deur Isebel (2:20) daarin dat laasgenoemde twee melding maak dat hulle die gelowiges verlei het "om afgodsoffers te eet en onsedelikheid te bedrywe" $(2: 14,20)$. Hier gaan dit dus om deelname aan heidense praktyke. Hierteenoor het die Nikolaiete waarskynlik eerder die gevaar ingehou dat van

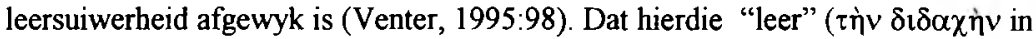
2:15) ook die dade van die gelowiges geraak het, blyk daaruit dat 2:6 melding maak van die "werke" ( $\tau \dot{\alpha}$ ह̌ $\tilde{p} \gamma \alpha$ ) van die Nikolaïete. Daarom was hulle leer so gevaarlik. Die gelowiges moes hierdie leer "gehaat" het $(2: 6,16)$. Dit is onbekend wat die leer van die Nikolaïete was (uitsprake daaroor is blote gissings), maar dit was 'n besliste bedreiging vir die gelowiges waarteen hulle volhardend weerstand moes gebied het en - waar nodig - dit moes ontmasker het.

\subsubsection{Verslapping}

Van die gemeente in Efese word gesê dat "hulle hulle eerste liefde verlaat het" (2:4) en van Sardis word beweer "dat hulle die naam het dat hulle leef maar hulle is dood" (3:1). Laodisea se gemeente word vermaan dat hulle "nie koud of warm" is nie (3:15). In al hierdie gevalle is die probleem dat hulle nie volhardend uit die evangelie geleef het nie, daarom word hulle vermaan om te onthou, om hulle te bekeer en om die eerste werke te doen (2:5).

Wat die redes vir die verslapping van die gelowiges was, kan slegs by wyse van afleiding geformuleer word. Schüssler Fiorenza (1986:136) wys op die verdrukking, vervolging en vyandigheid wat die Christene se geloof in God onder druk geplaas het. Hemer (1986:11) toon aan dat die gesag van die evangelies, wat in daardie tyd te boek gestel is, waarskynlik deur die Jode betwyfel sou gewees het. Dit sou ook groot druk op die gelowiges geplaas het. Die algemene knellende omstandighede waarin die gelowiges geleef het, sou van hulle groot votharding vereis het. Hulle is eksplisiet en implisiet opgeroep om nie in hulle geloof te verslap nie.

\subsubsection{Gevolgtrekking}

Openbaring bied duidelike gegewens dat die kerk bedreig is deur aanslae van buite af (die Jode, die owerheid, die gemeenskap) en verleidinge en afdwalinge van binne af, asook deur die gevaar van verslapping van lidmate. Dit is opsigtelik dat die oproep om in sulke situasies te volhard baie aktueel is, want die kerk is deur die eeue heen deur soortgelyke gevare bedreig. 
Dit is ook duidelik dat die kerk bemoedig moet word en versterk moet word om enigsins te kan volhard. Daarom word vervolgens ingegaan op die teosentriese begronding wat Openbaring stel en ook laastens hoe die gelowiges inderdaad prakties volhard het.

\section{Openbaring beskryf God se inisiatief met die kerk}

Openbaring het 'n baie pertinente teosentriese perspektief wanneer die posisie van die kerk beskryf word. Hierdie Godgerigtheid blyk uit sowel die feit dat God die kerk saamstel as dat Hy die kerk in die wêreld bystaan en versterk.

\subsection{God stel die kerk saam}

\subsubsection{Die werk van God die Vader}

God spreek die sewe gemeentes in Klein-Asië aan $(1: 4,5)$ en Hy word as die absoluut-sentrale Persoon gestel: Aan Hom kom toe "die heerlikheid en die krag tot in alle ewigheid" ( $1: 6)$ en Hy is "die Alfa en die Omega, sê die Here God, wat is en wat was en wat kom, die Almagtige" (1:8). Die woord $\pi \alpha v \tau o \kappa \rho \alpha ́ \alpha \omega \rho$ ("Almagtige regeerder van alles") is 'n Woord wat net in 1:8 gebruik word en dui hier spesifiek op die werk van die Vader (Venter, 1995:175). Hierdeur word die inisiatief van God duidelik omlyn, ook in die oorsprong, bestaan en voortbestaan van die kerk.

Die besondere verhouding tussen die werk van God en die volharding van die

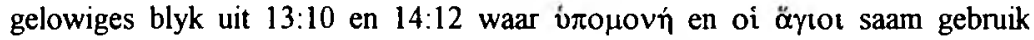
word: "Hier is die volharding van die heiliges (nodig)". Hierdie verbinding blyk ook uit 22:11 waar gesê word: "Laat die heilige (ó ă $\gamma \mathbf{l o \zeta}$ ) nog heiliger word ( $\dot{\alpha} \gamma\llcorner\alpha \sigma \theta \dot{t} t \omega)$ ", waar 'n proses van volharding beskryf word van diegene wat deur God reeds verlos is (heilig gemaak is) (Venter, 1995:185).

Die uiteindelike sekerheid van die gelowige, die gegewe dat sy naam simbolies in die boek van die lewe geskryf is $(3: 5 ; 13: 8 ; 20: 15 ; 22: 19)$, gee hom die krag tot volharding, want dit is ' $n$ "divine certification of a position and of corresponding rights with the Lord" (Lenski, 1963:134).

\subsubsection{Die werk van Jesus Christus}

Jesus Christus is inderdaad die sentrum en brandpunt van die kerk (vgl. Hughes, 1990:26), ook waar Hy tussen die sewe goue staanlampe staan (1:13). Die verlostes is "uit die mense losgekoop as eerstelinge vir God en vir die Lam" (14:4) (1983-vert.) Omdat God die gelowiges, die "getroues" ( $\pi$ totoí in 17:14) "geroep en gekies" (17:14) het, het hulle die basis gehad om getrou in hulle diens 
te volhard. Die feit dat Jesus ook die Getroue genoem word $(1: 5 ; 3: 14 ; 19: 11)$, sou die gelowiges versterk het in hulle lewe van volharding.

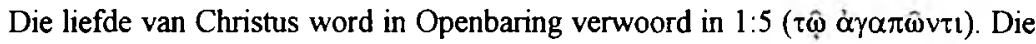
verlossende werk van Jesus is uit goddelike liefde gedoen (vgl. Coetzee, 1988: 299). Jesus is Koning van sy kerk (1:6) wat die mag besit tot die toegang tot sy koninkryk (1:18). Die opmerklike is dat Openbaring beskryf dat Jesus Christus nie sy mag en gesag by wyse van 'n veldslag verkry het nie, maar deur sy bloed $(5: 6 ; 12: 11)$ wat Hy gestort het. So is die liefde van Christus, die bloed van die Lam, die basis vir die oorwinning van die gelowige in die Naam van Jesus.

Daarmee het Jesus bepaalde seggenskap oor die gelowiges sodat Hy hulle met gesag kan vermaan om deel van die kerk te wees en te bly. Omdat Hy hulle ken $(2: 2,9,13,19 ; 3: 1,8,15)$ roep Hy hulle op tot bekering $(2: 5,16 ; 3: 3,19)$, tot getrouheid $(2: 10)$, standvastigheid $(2: 25 ; 3: 11)$ en om wakker $(3: 2)$ en ywerig (3:19) te wees. Hier is dit pertinente, implisiete en eksplisiete oproepe om te volhard vanuit die perspektief dat die kerk aan hulle Koning verantwoording verskuldig is.

Die eskatologiese troos dat Jesus weer kom $(1: 7 ; 2: 25)$ en dat Hy gou kom (3:11; $22: 7,12,20)$ beskryf sy "... teosentriese segetog ..." waarin Hy "sy lydende en strydende bruidskerk op aarde oorwinnaars saam met Hom (17:14) en so méér as oorwinnaars" (Du Preez, 1979:19) maak.

\subsubsection{Die werk van die Gees}

Ook die Gees is betrokke by die samestelling en die voortgang van die kerk. Die woorde "sewe Geeste van God" in 1:4, 3:1, 4:5 en 5:6 dui simbolies op die Heilige Gees (Venter, 1995:178) en dit maak Hom deel van die werk van die Drie-enige God wat sy kerk saamstel en regeer. Die gemeentes moet luister "na wat die Gees vir die gemeentes sê" $(2: 7,11,17,29 ; 3: 6,13,22)$. Die Gees is ook betrokke by die roep van die kerk in 22:17: "Die Gees en die bruid sê: Kom!" Hier is 'n roep tot Jesus om te kom, waarby die tweede roep aansluit: "Laat hom wat hoor, sê: Kom!" - wat 'n roep tot medegelowiges kan verwoord. Die gelowiges, wat hierdie boodskap hoor (vgl. 1:3), word opgeroep om saam tot Jesus te roep onder leiding van die Gees. Die derde roep, "Laat hom wat dors het, kom", kan gesien word as “... 'n uitreikende, uitnodigende roep tot die mens in stryd ('dors') ..., wat die afdwalende gelowiges en veral die ongelowiges insluit, om ook deel te word van hierdie roep van die kerk en so ook deel te word van die lewewekkende Evangelie van Jesus Christus" (Venter, 1995:180; vgl. Harrington, 1993:223, 225-226). 


\subsubsection{Gevolgtrekking}

Die werk van die Vader, die Seun en die Gees, is 'n bepalende faktor in die volharding van die gelowiges. Openbaring maak dit duidelik dat die gelowiges, die kerk, nie bestaan omdat die mens dit so bepaal nie. Daarom word die volhardende lewe van die gelowige gedra deur die feit dat God sy lewe begin het en dat Hy ook die voortgang van sy geloofslewe bepaal. Die gelowiges was versterk deur hierdie goddelike inisiatief van God, hulle Koning (15:3) en van Jesus as Koning van die konings $(17: 14 ; 19: 16)$ sodat hulle as konings in sy koninkryk (1:5) kon leef onder leiding van die Gees.

\subsection{God laat die kerk oorwin}

Die gebruik van die werkwoord vıkó $\omega$ is veelseggend: dié werkwoord word in die praesens gebruik wanneer die subjek 'n gelowige is wat nog nie sy opdrag om te oorwin, voltooi het nie (bv. 2:7, 11, 17 ens.; 21:7) en wanneer die gelowiges tot die end toe getrou gebly het, word die aoristus gebruik (12:11) (Aune, 1966:139). Die kerk word in hierdie proses van oorwinning geteken vanuit die perspektief van die sekerheid dat die finale oorwinning vir seker is. Laasgenoemde feit word eksplisiet voorgestel in die oorwinning oor die draak in 12:11.

Hierdie oorwinning van die kerk oor die draak word in 12:1 simbolies voorgestel deur die kroon met twaalf sterre op die hoof van die vrou, die beeld van die kerk in Openbaring. Die kerk is 'n oorwinnende kerk.

Die neerlaag van die Satan word reeds in 3:9 in die briefboodskap aan Filadelfia aangekondig: Dié wat uit die sinagoge van die Satan is, sal voor die gemeente kom neerbuig. "Christus gee die waarborg dat die Satan 'n neerlaag in hulle midde sal ly" (Grové, 1989:144). Hierdie neerlaag geskied enersyds op grond van die oorwinning van Jesus Christus, maar andersyds realiseer die oorwinning op grond van die feit dat die gemeente "die woord van my volharding (

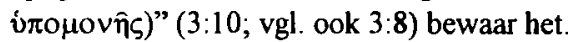

Die oorkoepelende gedagte wat uit Openbaring blyk, is dat die kerk (die gelowige) as oorwinnaar geteken word. Hierdie oorwinning van die gelowiges word enkel en alleen in die oorwinning van Christus veranker (Nikolainen, 1963:359; Reddish, 1982:133). Oorwinning en volharding is die weg waarlangs die kerk die oorwinning van Jesus Christus beleef. So ondervind die kerk die inisiatief van God in die bestaan van elke gelowige.

\subsection{Gevolgtrekking}

Die dade van God is die enigste basis vir die gelowiges om enigsins te kan volhard teen die aanslae wat teen die kerk gerig word. Die troos vir die 
gelowiges was (en is vandag nog) dat die mag van God (Vader, Seun en Gees) so oorweldigend is dat die aanslae teen die gelowiges daardeur afgeweer kan word. Die versekering wat Openbaring bied dat die oorwinning deur God vas en seker is, is 'n kragtige begronding vir die gelowige om te kan volhard. Daarom word vervolgens gelet op die praktiese dade van die volhardende gelowige volgens Openbaring.

\section{Openbaring beskryf die kerk in sy volhardende aktiwiteite}

Openbaring bied gegewens om te verstaan hoe die kerk die leiding en inisiatief van God in die moeilike omstandighede op aarde moet uitleef. Daar word egter nie op alle aspekte van die gelowiges se lewe ingegaan soos wat dit eksplisiet en implisiet beskryf word in Openbaring nie. Slegs die belangrikste en omvattendste aspekte van die kerk se bestaan word hier geraak.

Agtereenvolgens word gewys op die gegewens in Openbaring oor die getuieniskarakter, die liturgiese aktiwiteite van die kerk en laastens die suiwerende aksies in die kerk.

\subsection{Openbaring beskryf die getuienistaak van die kerk}

Die kerk is die draer van "die getuienis van Jesus" $(1: 2,9 ; 12: 17 ; 19: 10 ; 20: 4)$. Hier is waarskynlik sprake van sowel 'n subjektiewe genitief (die getuienis wat Jesus self gee) asook 'n objektiewe genitief ('n getuienis aangaande Jesus). Die hele Openbaring is 'n getuienis van Jesus en oor Jesus. Albei hierdie betekenisse van die genitief blyk ook uit 19:10: “... want die getuienis van Jesus is die gees van die profesie" (1953-vert.). "Die kerk moet van Jesus bly getuig, en hierdie inhoud is niks anders as om die getuienis van Jesus, soos dit blyk uit sy lewe, lering, sterwe en opstanding, onder leiding van die Gees te verkondig nie" (Venter, 1995:195).

Die feit dat die gelowiges getuies is, word veral in 1 1:3-12 beskryf in die visioen van die twee getuies. Die standpunt word gehuldig dat hierdie twee getuies nie net op 'n sekere groep in die kerk, naamlik op die martelare dui nie. Alle gelowiges het hier betrekking. Ook moet die twee getuies nie slegs tot twee spesifieke persone beperk word nie (bv. Moses en Elia of Elia en Elisa of Petrus en Paulus). Eerder kan dit beskryf word as 'n simboliese voorstelling van die getuieniskarakter van die kerk (vgl. Botha, 1965:194; Beasley-Murray, 1974: 181; Harrington, 1993:121).

Die gesamentlike verbondenheid van die kerk in sy getuienis word onderstreep deur die feit dat Openbaring 11 twee getuies beskryf. Die gelowige word deur medegelowiges versterk om met volharding te getuig. Die feit dat hierdie 
getuienis se tydperk beskryf word as eenduisend tweehonderd en sestig dae (en nie in maande of in jare nie) kan daarop dui dat die gelowige elke dag moet getuig (Botha, 1965:195). Die gelowige word hierin ook deur die Gees van God bygestaan, soos blyk uit die beskrywing van die getuies as die "twee olyfbome en twee kandelare" (11:4) - waar die kandelare, olyfbome en olie op die werk van die Gees betrekking kan hê (Du Preez, 1971:52).

Dit is duidelik uit 11:3-12 dat alle getuies die gevaar loop om teenstand te ondervind, tot selfs die vlak van martelaarskap en in uiterste gevalle selfs die dood. Dit sal van elke gelowige verwag word om in hierdie situasie te volhard.

In 11:5, 6 word die kerk bemoedig deur die feit dat die kerk krag (om te "verteer" - 11:5) en ook mag ( $\hat{\varepsilon} \xi o v \sigma i \alpha$ - in 11:6) het om sy getuienistaak uit te voer. Volgens die gebruik van $\delta \varepsilon \hat{\imath}$ "moet" dit gedoen word. Die mag van die kerk word in 11:6 beskryf met 'n verwysing na die mag wat Elia en Moses gehad het - wat daarna verwys dat die gelowiges deur gebed selfs mag oor die natuur kan hê (Sweet, 1979:186; Harrington, 1993:123).

Die kerk is verder bemoedig om in hulle getuienis te volhard as dit uit 11:7 blyk dat hulle hulle getuienis sou voltooi $(\tau \varepsilon \lambda \varepsilon \sigma \omega \sigma \iota v)$. Ten spyte van al die teenstand wat die kerk sal ervaar, soos in 11:7 beskryf, sal niks hierdie getuienis kan stop voordat God nie bepaal het dat dit voltooi is nie (Beasley-Murray, 1974:185).

Bogenoemde gegewens dui op 'n kragtige begronding vir die kerk om in sy getuienis oor Jesus te volhard en so deel te wees van die getuienis van Jesus self - Hy wat deur hulle getuig het.

\subsection{Liturgiese aktiwiteite}

Sommige verklaarders sien die gegewens in Openbaring oor die liturgiese handelinge as 'n neerslag van of die seremonies wat destyds in die keiserlike hof en kultus gebruiklik was (Aune, 1983:5) of die Ou-Testamentiese (Joodse) liturgie (Aune, 1983:23). Hierteenoor word gestel dat daar waarskynlik genoegsame reeds bestaande Christelike liturgiese handelinge was wat as basis vir die beskrywing van die liturgiese handelinge in Openbaring kon dien - wat nie uitsluit dat pertinente Ou-Testamentiese vertrekpunte gegeld het nie. "Die liturgiese besonderhede in Openbaring kan dus enersyds deskriptief wees as beskrywend van dit wat reeds in die kerk plaasgevind het en andersyds ook gelyktydig preskriptief as voorskrywend van waaruit die liturgiese handelinge van die kerk behoort te bestaan" (Venter, 1995:197).

Die besonderhede oor die liturgiese handelinge in Openbaring moet ook op die handelinge van die kerk op aarde gerig word (De Silva, 1992:300). "Dit beteken dat, wanneer die ouderlinge om God se troon Hom met 'n loflied prys, is dit asof 
die kerk self daarin saamsing" (Venter, 1995:198; vgl. Du Rand, 1993:318). Hierdie uitgangspunt bied ' $n$ kragtige begronding vir die volharding van die kerk op aarde: ten spyte van die sondige bestaan waarin die kerk verkeer, word die kerk se harte opwaarts verhef waar die lofsange voor die troon van God weerklink. Daarmee het die liturgiese handelinge van die kerk nie slegs 'n aardsgerigtheid nie, maar is dit inderdaad hemelsgerig (vgl. Peterson, 1988:77).

Die liturgiese handelinge van die kerk "... laat blyk dat die kerk nie net defensief volhard om teenstand teen die probleme te bied nie, maar ook positief volhard deur gesamentlik die heerskappy van God te erken, Hom daarvoor te loof en daarvolgens te leef" (Venter, 1995:198).

\subsubsection{Voorlesing van Openbaring}

Openbaring is self bedoel om liturgies aangewend te word (Gager, 1975:56; Vanni, 1991:370) in die sin dat dit volgens 1:3 in die gemeente voorgelees moes word. Hierdie liturgie het waarskynlik op "die dag van die Here" (1:10) plaasgevind (Vanni, 1991:371) sodat die gemeente kon hoor wat die Gees aan die gemeentes sê ( $2: 7$ e.a.).

Die afleiding uit 1:3 is dat hierdie boek hardop gelees moes word (Morris, 1969:46; Gager, 1975:56). Sommige verklaarders wys op die belangrikheid dat hierdie boek nie net individueel nie, maar juis ook gesamentlik gelees moet word (Schüssler Fiorenza, 1991:40). "Dit alles onderstreep die liturgiese karakter van Openbaring en dien tot versterking van die gelowiges se gesamentlike volharding in hulle kennis en uitlewing van die inhoud van God se Woord en van Openbaring in die besonder" (Venter, 1995:199).

Hierdie gegewens stem ooreen met die narratiewe aard van Openbaring: dit is " $n$ vertelling waar daar 'n lewende dialoog tot stand kom tussen die hemelse Skrywer en sy kerk" (Venter, 1995:199).

\subsubsection{Die lofliedere}

Die inhoud van die lofliedere word nie in hierdie artikel volledig bespreek nie (vgl. Venter, 1995:199-201). Wat wel veelseggend is, is dat alle aspekte van die lofprysende kerk daarin verwoord word: God word geprys (19:5), gedank (o.a. 4:9), geloof (o.a. 5:12,13), geëer (o.a. 15:4), heerlikheid toegebring (o.a. 4:9,11) en eer toegesing (o.a. $4: 9,11$ ). Verskillende dade van God word besing, sodat die lofliedere beskryf kan word as 'n weergawe van die basiese elemente waarin die gelowiges glo (vgl. Wolff, 1981:197). Dit verwoord die fondament op grond waarvan die kerk volhard.

Die feit dat die lofliedere in Openbaring gesing word deur onder andere of die vier lewende wesens $(4: 8)$ en/of die ouderlinge $(5: 9 ; 11: 17,18)$ en/of die engele 
(5:12) en/of die hele skepping (5:13) dui op die gesamentlike en kollektiewe aard van hierdie lofliedere. Die hele kerk word saamgebind as 'n lofprysende menigte (Aune, 1983:20).

Die lofliedere, as deel van 'n hemelse visioen, stel die gelowiges voor die plek, die majesteit van God, waarop alle lofliedere gerig moet wees. Daarmee vestig die kerk sy oog op die hemelse majesteit van God en is die singende kerk reeds nou al jubelend deel van hierdie oorwinning van die kerk van Christus. "Die lofliedere in Openbaring lê 'n versterkende en selfs emosioneel-gelaaide fondament vir die volharding van die gelowiges" (Venter, 1995:201).

\subsubsection{Die gebede}

Volgens 5:8 en 8:3, 4 word die gebede van die gelowiges voor die troon van God gebring. Die gelowiges kan in die wierook voor die troon van God hulle gebede herken (Harrington, 1993:104). In 8:1-4 word die belangrikheid van die gebede van die gelowiges dramaties onderstreep as dit volg op die gespanne afwagting op die oordele van God, gesimboliseer deur die halfuur stilte en as dit gestel word dat die oordele van God eers teruggehou word totdat hierdie gebede voor God se troon gebring is (Morris, 1969:120).

Hier is sprake van al ( $\pi \alpha v \tau \hat{\omega} v$ in 8:3) die gelowiges se gebede, individueel en gesamentlik. Hier kan aangesluit word by die gesamentlike roep van die gelowiges in 6:10: "Hoe lank nog, heilige en getroue Heerser? Wanneer voltrek U die oordeel en wreek U ons dood op die bewoners van die aarde?" (1983-vert.). Hier bid die gelowiges saam dat die eer van God gehandhaaf word.

Die gebruik van die woord $\pi \rho 0 \sigma \kappa u v e ́ \omega$ ("aanbidding") is veelseggend. Hierdie woord dra die betekenis om voor God, of in die geval van heidene voor die afgod, neer te strek en sy voet of die soom van sy kleed te soen (Mounce, 1977:139). Die woord dui op nederigheid en onderdanigheid (Peterson, 1988:68-69). Enersyds word hierdie woord gebruik wanneer gelowiges, en soms ook ongelowiges, God aanbid $(4: 10 ; 5: 14 ; 7: 11 ; 11: 1,16 ; 14: 7 ; 15: 4 ; 19: 4,10 ; 22: 9)$ en andersyds dui dit ook op die aanbidding van die anti-goddelike magte (13:4, 8, $12,15 ; 14: 9,11 ; 16: 2 ; 19: 20)$. Aanbidding maak die skeiding tussen geloof in God of die Satan sigbaar (Bauckham, 1993:59). Hierdie skeiding blyk duidelik uit 13:10 (waar die woord únopovń by name genoem word) en wat volg op 13:8 waar van die aanbidding van die dier sprake is. Dieselfde geld vir 14:12. In 14:12

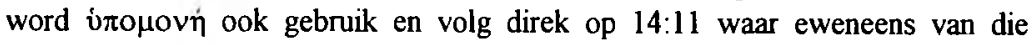
aanbidding van die dier sprake is. Die afleiding kan gemaak word dat die reaksie van die kerk op die bedreiging van die aanbidding van die dier telkens volharding is. Teenoor die aanbidders van die dier staan telkens die gesamentlike aanbidders van God. 
"Die gesamentlike biddende en aanbiddende kerk is die sigbare vergestalting van die gesamentlike volharding van die gelowiges teenoor die kollektiewe aanslag van die draak en sy trawante. Hierin lê 'n kragtige begronding van die volharding van die gelowiges" (Venter, 1995:203).

\subsubsection{Suiwering van die kerk}

Die perspektief van Openbaring is dat die kerk 'n gesuiwerde kerk is, soos blyk uit 11:1, 2: die tempel word gemeet en diegene wat buite die tempel is, word weggelaat. "Wat nie werklik tot die kerk behoort nie, word deur God verlaat en laat vaar" (Botha, 1965: 188).

Dit is insiggewend dat die roep tot bekering, spesifiek waar die woord $\mu \varepsilon \tau \alpha v o \varepsilon ́ \omega$ gebruik word, enersyds op die kerk/gemeente gerig word $(2: 5,16 ; 3: 3,19)$ en ook op individue van toepassing gemaak word $(2: 21,22 ; 9: 20,21 ; 16: 9,11)$. Hier word op eersgenoemde gebruik gekonsentreer, wat uiteraard impliseer dat die gelowiges hulle gesamentlik en individueel moet bekeer.

Die duidelike oproep tot 'n gemeente om hom te bekeer is 2:5 waar van Efese gesê word dat sy lampstaander verwyder sal word as hy hom nie bekeer nie. In 2:16 word die gemeente as geheel aangespreek met die woorde: "bekeer jou". Hierdie oproep tot gesamentlike bekering dui daarop dat elke individuele gelowige betrokke is by dit wat met die kerk gebeur. 'n Individu kan hom nie van die res van die kerk of gemeente losmaak nie - anders gaan hy saam met die geheel ten gronde.

Volgens Openbaring is dit die opdrag aan die gelowiges om die gebooie van God

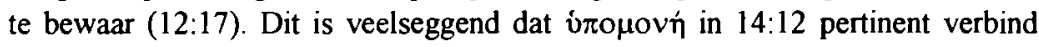
word aan diegene wat die gebooie van God en die geloof in Jesus bewaar. Volharding is 'n inherente aspek van die suiwering van die kerk.

Jesus word in Openbaring 2 en 3 beskryf as die Een wat die skerp tweesnydende swaard het $(2: 12)$ met oë soos 'n vuurvlam $(2: 18)$, wat niere en harte deursoek (2:23) en wat die dwaalleer haat $(2: 15,16)$. Hier is sprake van 'n dissiplinêre faset in die beskrywing van Jesus (Grové, 1992:139). Jesus se vermaning geskied in liefde teenoor die gelowiges (3:19), maar dit verander nie die feit dat $\mathrm{Hy}$ noulettend ag slaan daarop dat die kerk suiwer bewaar moet bly nie $(2: 14,20,22$, 23) en dat Hy aan elkeen volgens sy werke gee nie $(2: 5,23 ; 3: 2,16)$.

\subsection{Gevolgtrekking}

Openbaring beskryf die dade van die gelowiges (die kerk) as 'n kerk wat inderdaad volhard het. Enersyds het hulle defensief die aanslae van die Satan weerstaan en het sodoende daadwerklik die kerk gesuiwer van bederwende invloede. Andersyds was hulle positief besig om die oorwinning in Christus uit te 
leef deur vir Hom te getuig. Hulle het 'n lewende liturgiese aktiwiteit beoefen om God by wyse van Skriflesing, lofliedere en gebede te prys en uit te leef dat hulle deel is van die oorwinnaarsvolk van God.

\section{Samevatting}

Die oogmerk van hierdie artikel was om te bepaal watter boodskap die kerk uit Openbaring kan kry om in die moeilike omstandighede van die wêreld te volhard. Die volgende aspekte het geblyk die kern van hierdie boodskap te wees.

As apokalips leen die Openbaring aan Johannes hom uitnemend daartoe om die gelowiges onder die indruk te bring van die intensiteit van die aanslag van die Satan teen die kerk. Maar in dieselfde apokaliptiese taal word die gelowige bemoedig deur die allesoorheersende oorwinning wat deur Jesus Christus behaal is. Die feit dat God in beheer is en deur die bloed van die Lam die oorwinning verseker, bied in hierdie apokaliptiese beskrywing 'n sterk begronding vir die oproep tot volharding van die gelowiges.

Openbaring bied omvattende gegewens oor die oproep en aanmoediging tot die gelowiges om te volhard. Enige gelowige wat hierdie boek lees, kom onder die besef van die dringendheid om nie te verslap nie, maar om waaksaam te wees. Die gelowige vandag moet nie in hierdie waaksaamheid verslap nie. Hiertoe moet die kerk deur getroue Woordbediening gedurig die gelowiges oproep sodat die kerk as 'n gesuiwerde kerk die oorwinning nou al kan beleef.

Die gelowiges moet by die lees van Openbaring opnuut onder die besef kom dat elke daad vall volharding betekenis het vir die kerk van Christus. Die gelowiges lewer 'n bydrae as 'n getuienis dat die Bose nie oorwin nie, maar dat Christus steeds aan die oorwin is. Die gelowige moet ook sy medegelowiges versterk deur as voorbeeld te dien van hoe 'n gelowige moet en kan volhard. Die gelowiges moet mekaar nie alleen laat nie, want die aanslag is heftig.

\section{Literatuurlys}

AUNE, DE 1966. St John's portrait of the church in the Apocalypse. The Evangelical Quarterly, 38(3): 131-149.

AUNE, DE. 1983. The influence of Roman imperial court ceremonial on the Apocalypse of John. Biblical Research, 28:5-26.

BAUCKHAM, R. 1993. The theology of the Book of Revelation Cambridge : Cambridge University.

BEASLEY-MURRAY, G.R 1974. The Book of Revelation. London : Oliphants (New Century Bible.)

BOTHA, F.J. 1965. Die kerk in die Openbaring aan Johannes. Pretoria : Universiteit van Pretoria (D. D.-proefskrif.)

CHARLES, R. H 1920a. A critical and exegetical commentary on the Revelation of St John. Vol. I Edinburgh : Clark. (Intemational Critical Commentary.) 
CHARLES, R.H. 1920b A critical and exegetical commentary on the Revelation of St. John. Vol. 2. Edinburgh : Clark. (International Critical Commentary.)

COETZEE, J C 1988. Die prediking (teologie) van die Openbaring aan Johannes (In Du Toit, A.B, red Handleiding by die Nuwe Testament. Pretoria : NG Kerkboekhandel. p. 253 314.)

COLLINS, A.Y. 1983. The Apocalypse. Wilmington : Michael Glazier (New Testament Message).

COLLINS, A.Y. 1988. Oppression from without: The symbolization of Rome as evil in early Christianity. Concilium, 200:66-74.

DE SILVA, D A. 1992. The social setting of the Revelation to John: Conflicts within, fears without. Westminster Theological Journal, 54(2) 273-302.

DU PREEZ, J. 1971. The Holy Spirit and the church in the Book of Revelation. Kerugma, 11:48-54.

DU PREEZ, J. 1979. Die koms van die koninkryk volgens die boek Openbaring. Stellenbosch : Universiteit van Stellenbosch. (Annale, serie B, nr. 1.)

DU RAND, JA. 1990. Johannese perspektiewe. Inleiding tot die Johannese geskrifte Orion: Pretoria. Deel 1.

DU RAND, J.A 1993. 'Now the salvation of our God has come ...' A narrative perspective on the hymns in Revelation 12-15. Neotestamentica, 27(2):313-330.

FULLER, J.W. 1983. "I will not erase his name from the Book of Life" (Revelation 3:5). Journal of the Theological Society, 26(3):297-306.

GAGER, J. 1975. Kingdom and community: The social world of early Christianity. Englewood Cliffs : Prentice-Hall.

GROVÉ, A.H 1989. Die Bose en die kerk volgens Openbaring 2 en 3. Bloemfontein : UOVS (M.A.-verhandeling)

GROVE, AH. 1992. Die selfidentifikasie van Christus in Openbaring 2 en 3. Potchefstroom : PU vir CHO. (D.Litt.-proefskrif.)

HARRINGTON, W.J. 1993. Revelation. Collegeville : Liturgical. (Sacra Pagina Series.)

HEMER, C.J. 1986 The Letters to the seven churches of Asia in their local setting. Sheffield : JSOT.

HILL, D. 1971. Prophecy and prophets in the Revelation of St. John. New Testament Studies, 18(4):401-418

HOPKINS, M. 1965 The historical perspective of Apocalypse 1-11. Catholic Biblical Quarterly, 27(1):42-47.

HUGHES, P.E. 1990 The Book of Revelation A commentary. Leicester : Inter-Varsity.

LENSKI, R.C.H 1963. The interpretation of St. John's Revelation Minneapolis : Augsburg

MATHEWS, S.F. 1993. On patient endurance. Bible Today, 31(5):305-312

MORRIS, L. 1969. The Revelation of St. John. An introduction and commentary. London Tyndale. (Tyndale New Testament Commentaries.)

MOUNCE, RH. 1977. The Book of Revelation. Grand Rapids : Eerdmans (The New International Commentary on the New Testament.)

NIKOLAINEN, A.T 1963. Der Kirchenbegriff in der Offenbarung des Johannes. New Testament Studies, 9:351-361

PETERSON, D.G. 1988. Worship in the Revelation to John. Reformed Theological Review, 47(3):67-77.

REDDISH, M.G 1982. The theme of martyrdom in the Book of Revelation. Ann Arbor : University Microfilms International (Ph.D.-thesis.)

SCHUSSLER FIORENZA, E. 1968. The eschatology and composition of the Apocalypse Catholic Biblical Quarterly, 30(4):537-569. 
SCHÜSSLER FIORENZA, E. 1980 Apokalypsis and propheteia: The Book of Revelation in the context of early Christian prophecy. (In Lambrecht, J., ed. L'Apocalypse johannique et l'apocalyptique dans le Nouveau Testament. Gembloux : Duculot p 103-128.)

SCHUSSLER FIORENZA, E. 1986. The followers of the Lamb: Visionary rhetoric and social-political situation. Semeia, 36:123-146.

SCHUSSLER FIORENZA, E. 1991. Revelation Vision of a just world. Philadelphia Fortress.

SWEET, J.P.M. 1979. Revelation. Philadelphia : Westminster.

VANNI, U 1991. Liturgical dialogue as a literary form in the Book of Revelation New Testament Studies, 37(3):348-372

VENTER, A.G.S. 1995. Volharding in teosentriese perspektief volgens die boek Openbaring. Johannesburg : Randse Afrikaanse Universiteit. (D.Litt. et Phil-proefskrif.)

WOLFF, C. 1981. Die Gemeinde des Christus in der Apokalypse des Johannes. New Testament Studies, 27(2):186-197. 
